\title{
Antimicrobial Activity of Lactic Acid Bacteria and the Spectrum of their Biopeptides Against Spoiling Germs in Foods
}

\author{
Fatima Djadouni ${ }^{1}$ and Mebrouk Kihal ${ }^{2 *}$ \\ ${ }^{1}$ Faculty of Sciences; Mascara of University; Algeria. ${ }^{2}$ Laboratory of Applied Microbiology; Department Biology; \\ Faculty of Sciences; Es-Senia University; Oran - Algeria
}

\begin{abstract}
The objective of this study was to isolate LAB from dairy, meat products and agro-industrial wastes and to investigate their antagonist activity. A total of 141 isolates were screened for the inhibitory effect on ten indicator strains in the agar spot test. Results showed that strain LBbb0141 contained antimicrobial compound with wide spectrum that inhibited the growth of ten indicator Gram-positive and Gram-negative strains. The bacteriocin activity attained its maximum value using the MRS agar at initial $p H 7.5$ and $30^{\circ} \mathrm{C}$ incubation temperature.
\end{abstract}

Key words: Lactobacilli, Enterocoquess, Leuconostoc sp, bacteriocins activities, indicators microorganisms, Listeria innovii, growth media, $\mathrm{pH}$, temperature

\section{INTRODUCTION}

Biopreservation systems in food are becoming increasingly interesting for the industry and consumers. Bacteriocinigenic lactic acid bacteria and/or their bacteriocins are considered safe additives (GRAS), useful to control the frequent developement of pathogens and spoiling microorganisms in food and feed. (Parada et al. 2007).

Alternative methods for controlling the pathogenic bacteria, including the production of antimicrobial peptides "bacteriocins", are now highly considered. Bacteriocins are compounds produced by the bacteria that have a biogically active protein moiety and bactericidal action (Line et al. 2008).

Bacteriocins from the Gram-positive microorganisms, such as lactic acid bacteria $(\mathrm{LAB})$, have attracted much attention and have been the subject of intensive investigation due to their extensive incorporation as biopreservatives ingredients into model food, particularly in the dairy industry (Diop et al. 2007) and also in human therapeutics (Martin Visscher et al. 2008).

\section{Lactic Acid Bacteria}

Lactic acid bacteria (LAB) are characterized as the Gram-positive cocci or rods, non-aerobic but aerotolerant, able to ferment the carbohydrates for energy and lactic acid production. The metabolic pathway from glucose may be homofermentative or heterofermentative. In the first case, two molecules of lactate are generated (as in Streptococcus and Lactococcus), and in the second, lactate, ethanol and carbon dioxide are produced, as in Leuconostoc and some lactobacilli. Lactic acid bacteria are also able to produce small organic substances that contribute with aroma and

*Author for correspondence: Kihalm@gmail.com. 
give specific organoleptic attributes to the products (Caplice and Fitzgerald 1999). These microorganisms are found in milk, meat and fermented products, as well as in fermented vegetables and beverages, inhibiting the growth of pathogenic and deteriorating microorganisms, maintaining the nutritive quality and improving the shelf life of foods. They have also been used as flavor and texture producers.

Lactic acid bacteria include various major genera: Lactobacillus, Lactococcus, Carnobacterium, Enterococcus, Lactosphaera, Leuconostoc, Melissococcus, Oenococcus, Pediococcus, Streptococcus, Tetragenococcus, Vagococcus and Weissella. Other genera are: Aerococcus, Microbacterium, Propionibacterium and Bifidobacterium (Carr et al. 2002). Lactobacillus acidophilus, L. plantarum, L. Casei, L. rhamnosus, L. delbrueckii bulgaricus, L. fermentum, L. reuteri, Lactococcus lactis lactis, Lactococcus lactis cremoris, Bifidobacterium bifidum, B. infantis, $B$. adolecentis, B. longum, B. breve, Enterococcus faecalis, Enterococcus faecium, are some of the most common species (Garrity 1984; Dellaglio et al. 1994), and some strains are recognized as probiotics (Fuller 1989; Parada et al. 2003).

Sugar fermentation followed by a reduction in $\mathrm{pH}$ due to the production of lactic and other organic acids is an important factor for the inhibition of growth of undesired microorganisms. The low $\mathrm{pH}$ makes organic acids lipossoluble, allowing them to break through the cell membrane and reach the cytoplasm of pathogens (Haller et al. 2001). The competition for essential nutrients, accumulation of D-amino-acids and diminution of the oxirredutive potential also contribute to their inhibitory effect. (Parada et al. 2007)

\section{MATERIALS AND METHODS}

\section{Bacterial strains}

The pathogenic and non-pathogenic indicator strains used in this work were provided by the Laboratory of Bacteriology, Microbiology Department at the Faculty of Sciences, Es-Senia, Oran University. They included both Gramnegative (Escherichia coli, Pseudomonas sp., Salmonella typhimurium, Salmonella paratyphimurium B, and Clostidium sp.) and Grampositive strains (Staphylococcus aureus, Streptococcus sp., Listeria ivanovii, Bacillus megaterium ID 07817 and Bacillus megaterium ID 07818).

\section{Isolation and selection of LAB strains}

LAB strains were isolated from the dairy, meat products and agro-industrial wastes (vegetables, fruits and fermented vegetables). The samples were plated directly on MRS and M17 agar (Merck, Germany) at $30^{\circ} \mathrm{C}$ for 2-3 days (pH6.5) under aerobiosis and anaerobiosis conditions. They were routinely propagated and stored at $20^{\circ} \mathrm{C}$ supplemented with glycerol $(20 \% \mathrm{v} / \mathrm{v})$. Working cultures were sub-cultured twice $(1 \%$ inoculum, $24 \mathrm{~h}, 30^{\circ} \mathrm{C}$ ) prior to use.

\section{Identification of the $\mathrm{LAB}$ isolates}

The pure isolate selected as a potential bacteriocin - producer was identified on the basis of its cultural, morphological, physiological and biochemical characteristics. The selected LAB isolates were characterized by Gram stain, absence of spores and catalase test. Gram + , catalase and spores negative strains were maintained frozen until needed for the antimicrobial activity testing (Cintas et al. 1998). Confirmation of the identification was based on the use of API 50 kits.

\section{Characterization and differentiation of bacteriocin producing $\mathrm{LAB}$}

Bacteriocin producing strains were stained and examined microscopically for cellular morphology and Gram-stain phenotype. Catalase activity was tested by spotting the colonies with $3 \%$ hydrogen peroxide. The growth was assayed in MRS broth at $10,15,37$ and $45^{\circ} \mathrm{C}$ as well as at $\mathrm{pH}$ of $3.5,4.5$, $5.5,6.5,7.5,8.5$ and 9.5 incubated at $30^{\circ} \mathrm{C}$. Salt tolerance was tested with 4.0,6.5, 10 and $15 \%$ (w/v) $\mathrm{NaCl}$ in MRS broth. Production of acid and $\mathrm{CO}_{2}$ from glucose was tested in MRS broth containing Durhams tube, with citrate omitted (Schillinger et al. 1987).

The production of ammonia in MRS broth omitting glucose and meat extract, while containing $0.3 \%$ arginine and $0.2 \%$ sodium citrate replacing ammonium citrate, was monitored using Nessler's reagent. Homo- and heterofermentative differentiation test was also carried out according to the method reported by Zuniga et al. (1993). Assays for gelatin hydrolysis and nitrate reduction were performed in accordance with Harrigan (1998). The ability to ferment various carbohydrates was evaluated using MRS broth supplemented with filter sterilized sugar solutions to a final concentration of $1 \% \mathrm{w} / \mathrm{v}$ and $0.004 \%$ chlorophenol red without glucose and meat extract (Schillinger et al. 1987). The configuration of lactic acid formed from glucose was determined 
enzymatically using D-lactate and L-lactate dehydrogenase.

The fermentation of carbohydrates (fructose, mannane, glucose, lactose, maltose, mannitol, mannose, melibiose, sucrose, trehalose and xylose) was performed in MRS broth (prepared without sugars) containing $1 \%$ solution of carbohydrate and added to $0.025 \%$ bromocresol purple as $\mathrm{pH}$ indicator. Results were recorded after $48 \mathrm{~h}$ of incubation at $30^{\circ} \mathrm{C}$.

\section{Antibiogram of LAB isolates}

The pure isolate selected as a potential bacteriocin producer was inoculated into MRS broth individually and incubated for $24 \mathrm{~h}$. About $25 \mathrm{ml}$ of MRS agar was seeded with the cultures of LAB isolate $\left(10^{6} \mathrm{CFU} / \mathrm{ml}\right)$, mixed well, poured into sterile Petri plates and stored at $4^{\circ} \mathrm{C}$ for $1 \mathrm{~h}$ to solidify the media. OCTA-discs (14 antibiotics in a single ring) were placed upside down, pressed on the top of the agar plates and kept again at $4^{\circ} \mathrm{C}$ for $1 \mathrm{~h}$. The plates were incubated at $30^{\circ} \mathrm{C}$ overnight. Resistance was defined as the absence of a growth inhibition zone around the discs.

\section{Inhibition of indicator strains by the selected LAB isolates}

The inhibitory activity of the selected LAB isolates against the indicator strains was assayed by the agar spot test described by Fleming et al. (1975). The LAB isolates were spotted onto the surface of MRS agar plates and incubated at $30^{\circ} \mathrm{C}$ for $24 \mathrm{~h}$ to allow the colonies to develop. The indicator strains were inoculated into $10 \mathrm{ml}$ of soft MRS agar ( $0.9 \%$ agar) and poured over the plate on which the LAB isolates were grown. After incubation at $30^{\circ} \mathrm{C}$ for $24-48 \mathrm{~h}$ under aerobiosis conditions, the plates were examined for the presence of inhibition zones. Inhibition was considered positive when the width of the clear zone around the colonies of the LAB isolates was $0.5 \mathrm{~mm}$ or larger.

Effect of growth media, incubation temperature and initial pH on the antimicrobial compounds activity

Commercial media such as MRS (De Man Rogosa Sharpe) agar, Brain Heart Infusion (BHI; Merck, Germany) agar and M17 (Merck, Germany) agar were tested for their suitability for bacteriocin activity using the agar spot method. The test strain was inoculated into each test medium, grown aerobically at three selected temperatures $(30,37$, and $45^{\circ} \mathrm{C}$ ). To determine the effect of $\mathrm{pH}$, MRS broth was adjusted with $1 \mathrm{~N}$ HCL or $1 \mathrm{~N} \mathrm{NaOH}$ to $\mathrm{pH}$ values of $3.5,4.5,5.5,6.5,7.5,8.5$ and 9.5 (Ougnbanwo et al. 2003a) after the addition of agar the medium was autoclaved. The indicator strain (Listeria ivanovii) was inoculated into $10 \mathrm{ml}$ of soft MRS agar (0.9\% agar) and poured over the plate on which the LAB isolates were grown. After incubation at $30^{\circ} \mathrm{C}$ for $24-48 \mathrm{~h}$ under aerobiosis, the plates were examined for the presence of inhibition zones.

\section{RESULTS}

A total of 141 isolates were obtained and screened for antimicrobial spectrum against the Grampositive and Gram-negative bacteria using the agar spot method. The average diameter of the inhibition zone measured ranged from $1-14 \mathrm{~mm}$ in size.

All the isolates obtained in this study were considered LAB based on their positive Gram reaction, non-motility, absence of catalase activity and of spore formation, and the rod or coccal shape. Three strains of LAB were selected, for further studies to compare them, because LBbb0141 contained antimicrobial compound with wide spectrum that inhibited the growth of representatives ten (10) indicator Gram-positive and Gram-negative strains; LBdc0103 contained an antimicrobial compound with a limited spectrum that inhibited the growth of six indicator strains; whereas LBc088 don't inhibited any indicator strain (Table 1).

The strain LBbb0141 isolated from the cow milk produced the maximum ihibition zone $(10-14 \mathrm{~mm})$ against all the tested microorganisms (Escherichia coli, Pseudomonas sp., Salmonella typhimurium, Salmonella para-typhimurium B, Clostidium sp., Staphylococcus aureus, Streptococcus sp., B. megaterium ID 07817 and $B$. megaterium ID 07818) and was maximum against Listeria ivanovii.

On the basis of morphological, physiological and biochemical characters as well as sugar utilization pattern, LBbb0141, LBc088 and LBdc0103 were identified as Lactobacillus sp., Enterococcus sp. and Leuconostoc sp. 
Table 1- Inibitory activity of LBbb0141 against lactic acid bacteria and other indicator strains.

\begin{tabular}{lccc}
\hline Indicator strains & LBbb0141 & LBc088 & LBdc0103 \\
\hline Listeria ivanovii & + & - & - \\
Bacillus megterium ID 07817 & - & - & + \\
Bacillus megterium ID 07818 & + & - & - \\
LBbb0141 & & - & - \\
LBc088 & - & & + \\
LBdc0103 & + & - & + \\
Salmonella typhimurium & + & - & + \\
Staphylococcus aureus & + & - & + \\
Salmonella para-typhimurium B & + & - & - \\
Streptococcuss sp. & + & - & - \\
Escherichia coli & + & - & - \\
Clostridium sp. & + & - & \\
Pseudomonas sp. & + & & \\
\hline
\end{tabular}

Legend: Inhibitory activity (+).

Table 2 - Morphological, physiological and biochemical properties of bacteriocin producing LAB isolate (LBbb0141).

\begin{tabular}{|c|c|c|}
\hline \multicolumn{2}{|c|}{ Tests } & Isolate/ LBbb0141 \\
\hline \multicolumn{2}{|c|}{ Morphology } & rod, circular and white colonies $3.0 \mathrm{~mm}$ \\
\hline \multirow{5}{*}{ Growth at temperature ${ }^{\circ} \mathrm{C}$} & 10 & + \\
\hline & 15 & + \\
\hline & 30 & + \\
\hline & 37 & + \\
\hline & 45 & + \\
\hline \multirow{7}{*}{ Growth at $\mathrm{pH}$} & 3.5 & - \\
\hline & 4.5 & + \\
\hline & 5.5 & + \\
\hline & 6.5 & + \\
\hline & 7.5 & + \\
\hline & 8.5 & + \\
\hline & 9.5 & $\mathrm{~W}$ \\
\hline \multirow{4}{*}{ Growth at $\mathrm{NaCl} \%$} & 4 & + \\
\hline & 6.5 & + \\
\hline & 10 & + \\
\hline & 15 & + \\
\hline \multicolumn{2}{|l|}{$\mathrm{CO}_{2}$ from glucose } & + \\
\hline \multicolumn{2}{|l|}{$\mathrm{CO}_{2}$ from gluconate } & + \\
\hline \multicolumn{2}{|l|}{ ADH } & + \\
\hline \multicolumn{2}{|l|}{ Citrate } & + \\
\hline \multicolumn{2}{|c|}{ Thermoresistance at $60^{\circ} \mathrm{C} / 30 \mathrm{~min}$ at $45^{\circ} \mathrm{C}$} & + \\
\hline \multicolumn{2}{|l|}{ Fermentation Type } & $\mathrm{He}$ \\
\hline \multicolumn{2}{|c|}{ Fermentation of : glucose, saccharose, et lactose. } & + \\
\hline \multicolumn{2}{|c|}{ Lait Sherman $(\mathrm{BM} 1 \%)$ at $42^{\circ} \mathrm{C}$} & + \\
\hline \multicolumn{2}{|c|}{ Lait Sherman (BM $3 \%)$ at $42^{\circ} \mathrm{C}$} & - \\
\hline \multicolumn{2}{|c|}{ Hydrolyse of caseine } & + \\
\hline \multicolumn{2}{|l|}{ Fructose } & + \\
\hline \multicolumn{2}{|l|}{ Mannane } & + \\
\hline \multicolumn{2}{|l|}{ Maltose } & + \\
\hline \multicolumn{2}{|l|}{ Trehalose } & + \\
\hline \multicolumn{2}{|l|}{ Manose } & + \\
\hline \multicolumn{2}{|l|}{ Melibiose } & - \\
\hline \multicolumn{2}{|l|}{ Palmitine } & - \\
\hline \multicolumn{2}{|l|}{ Raffinose } & + \\
\hline \multicolumn{2}{|l|}{ Xylose } & - \\
\hline \multicolumn{2}{|l|}{ Mannitol } & + \\
\hline
\end{tabular}

Legend: Growth (+), no growth (-), weak growth (w), heterofermentation (He). 
LBbb0141 strain was highly resistant to Ceftazidine, Nitroxiline, Acid pipemidic, Colistine, Penicilline, Amoxicitine, Gentamycine Oxacycline, Knamine and Sultamethoxazole, while it was sensitive for all other antibiotics examined. (Table 3 ).

The effect of growth media and incubation temperature on the antimicrobial activity showed that the highest inhibitory effect was obtained in MRS agar after $24 \mathrm{~h}$ of incubation at $30^{\circ} \mathrm{C}$; increasing the incubation of temperature had a significant adverse effect on active compounds concentration. (Table 4).

Table 3 - Antibiogram of bacteriocin producing LAB isolate (LBbb0141) determined by antibiotic sensitivity OCTA-discs.

\begin{tabular}{lc}
\multicolumn{1}{c}{ Antibiotics } & LBbb0141 \\
\hline Ceftazidine & - \\
Pefloxacin & $+\left(5^{*}\right)$ \\
Nitroxiline & $+\left(2^{*}\right)$ \\
Spiramycin & - \\
Acid pipemidic & - \\
Colistine $50 \mathrm{mg}$ & $+(2 *)$ \\
Neumycine & - \\
Penicilline & - \\
Amoxicitine & - \\
Gentamycine & - \\
Oxacycline & - \\
Knamine $30 \mathrm{mg}$ & - \\
Sultamethoxazole $1.25-23.7 \mathrm{mg}$ & $+(4 *)$ \\
Spiro $100 \mathrm{mg}$ &
\end{tabular}

Legend: Sensitive (+), resistant (-).

*: The zone inhibition diameter on $\mathrm{mm}$.

Table 4 - Influence of growth media (MRS, M17 and BHI; pH6.5) on the inhibitory activity against L. ivanovii.

\begin{tabular}{ccccc}
\hline \multirow{2}{*}{ Temperature } & & \multicolumn{3}{c}{ LAB isolates } \\
\cline { 2 - 5 } $30{ }^{\circ} \mathrm{C}$ & MRS & $10 * \pm 1$ & LBc088 & LBdc0103 \\
& M17 & - & - & $2 \pm 0.5$ \\
& BHI & - & - & - \\
$37^{\circ} \mathrm{C}$ & MRS & - & - & - \\
& M17 & - & - & - \\
& BHI & - & - & - \\
& MRS & - & - & - \\
\hline
\end{tabular}

*: The zone inhibition diameter on $\mathrm{mm}$. (-) absence of inhibitory activity of bacteriocin.

Different $\mathrm{pH}$ values ranging from 3.5-9.5 were used to test the production of bacteriocins by the three organisms under investigation (Table 5).

The results from Table 5 showed that the optimal antimicrobial compounds production by LBbb0141 was recorded in MRS agar with an initial $\mathrm{pH}$ of 7.5 , after $24 \mathrm{~h}$ at $30^{\circ} \mathrm{C}$. Using the same medium ( $\mathrm{pH}$ 6.5, and 9.5), the strain LBbb0141 showed a minimum activity against $L$. ivanovii. In general, low levels of bacteriocin activity were recorded when both the test strains LBbb0141 and LBdc0103 were cultured in MRS agar with an initial $\mathrm{pH}$ of 3.5. 
Table 5 - Influence of initial $\mathrm{pH}$ on the antimicrobial activity from LAB isolates (LBbb0141, LBc088 and LBdc0103) against L. ivanovii.

\begin{tabular}{cccc}
\hline pH & \multicolumn{3}{c}{ LAB isolates } \\
\cline { 2 - 4 } & LBbb0141 & LBc088 & LBdc0103 \\
\hline $\mathbf{3 . 5}$ & $2 * \pm 0.5$ & - & - \\
$\mathbf{5 . 5}$ & - & - & - \\
$\mathbf{6 . 5}$ & - & - & $1 \pm 0.5$ \\
$\mathbf{7 . 5}$ & - & - & - \\
$\mathbf{8 . 5}$ & $4 \pm 1$ & - & - \\
$\mathbf{9 . 5}$ & - & - & - \\
\hline
\end{tabular}

*: The zone inhibition diameter on $\mathrm{mm}$.

\section{DISCUSSION}

Maintaining a safe food supply has become an ever-changing endeavor as new information on pathogenic bacteria is discovered. Consumer demands for minimally processed foods means that the food industry can no longer rely on traditional methods of thermal processing to create the microbiologically safe foods. Minimally processed foods such as fresh fruits and vegetables have been shown to harbor pathogenic bacteria. Thermal processing of fresh fruits and vegetables is often not acceptable, so other methods of controlling the pathogenic bacteria must be considered. Methods such as irradiation, highpressure processing, low-temperature storage, chemical preservatives, modification of atmosphere, and control of water activity, or combinations thereof may be considered. The use of antimicrobial compounds found within the foods themselves may be another way of controlling microorganisms.

Bacteriocins are highly specific antibacterial proteins produced by the strains of bacteria active mainly against some other strains of the same or related species (Gaur et al. 2004). The bacteriocins produced by the LAB are potent biopreservative agents and the applications of these in food are currently the subject of extensive research. The search for new bacteriocins with wider spectrum of activity and compatibility with different food system is being studied by some investigators.

Fruits, vegetable waste and fermented food provide a good source for isolating the LAB having antagonistic and probiotic properties. However, work on bacteriocinogenic LAB from agro-based waste has been limited (Lade et al. 2006). In this work, the search for bacteriocin production by some LAB was undertaken.
Results obtained by Lewus et al. (1991) showed that only a few of the strains tested were positive when the spot-on-the-lawn method was used, and also gave positive results in the well-diffusion assay. They considered that allowing some time for the bacteriocins to diffuse into the agar prior to incubation, or increasing the well size so that more sample could be applied, might increase the sensitivity of the assay. According to these authors, aggregation, non-diffusible bacteriocins, medium composition, protease inactivation and concentration effects, could lead to false negative results in the well-diffusion assay.

Özlem and Feryal (2006) using $L$. casei and $L$. bulgaricus isolates showed weak antibacterial activity against $E$. coli, $S$. aureus, $P$. aeroginosa, B. subtilis, Klebsiella pneumonia, S. typhimurium, and Enterococcus cloacae. Abo-Amer (2007) reported that out of 73 isolated Lactobacillus strains, only four strains of L. plantarum (AA110, AA125, AA135 and AA140) demonstrated the production of antagonistic activity against food borne pathogens in the $\mathrm{LB}$ medium at $37^{\circ} \mathrm{C}$ by using agar well diffusion method. (Korenblum et al. 2005)

In this study, the test strains exhibited a broad antimicrobial spectrum, capable of being active against Gram-positive and Gram-negative representatives.

L. ivanovii was chosen as the important indicator strain because it has been the cause of a potential public health hazard and produced enterotoxins that caused food poisoning if ingested and deteriorated the organoleptic characterization of foods. De Kwaadsteniet et al. (2005) demonstrated that bacteriocin ST15 produced by Enterococcus mundtii ST15 was active against Gram-positive and Gram-negative bacteria such as Acinetobacter baumanii, B. cereus, C. tyrobutyricum, 
Enterococcus feacalis, K. pneumoniae, L. sakei, S. aureus and Streptococcus pneumoniae. Screening for the bacteriocin production of by the strains of LAB from various meat and meat products resulted in the detection of a bacteriocin-producing Lactococcus lactis subsp. cremoris CTC 204, isolated from the chicken (Bromberg et al. 2005). The bacteriocin inhibited not only the closely related LAB (L. helveticus), but also the pathogenic microorganisms ( $S$. aureus, $L$. monocytogenes, $B$. cereus and $C$. perfringens).

Abo-Amer (2007) found that the antimicrobial agent excreted by $L$. plantarum AA135 was the most active against a wide range of Gram-positive and Gram-negative pathogens. Earlier reports (Tagg et al. 1976; Daeschel et al. 1990; Sanni et al. 1999) have shown that some bacteriocins produced by the Gram-positive bacteria have a broad spectrum of activity. However, it was generally observed that bacteriocin from the producer organism had no inhibitory effect on the organism producing it. JoshiI et al. (2006) reported that the antimicrobial activity of partially purified bacteriocin produced during the natural lactic acid fermentation of carrot, radish and cucumber and characterized them. Out of ten strains, the isolated strain of Lactobacillus genus from the carrot fermentation produced bacteriocin with maximum antimicrobial activity against $E$. coli, S. aureus and $B$. cereus, though it was more effective against $E$. coli than others on growth in the MRS broth at $32^{\circ} \mathrm{C}$ for $24-48 \mathrm{~h}$. In another part of the same investigation, different experiments were designed to attain the best available cultural conditions which could help in the production of bacteriocins, with the least economical costs possible and with the simplest methods available. As large amounts of bacteriocin are necessary to test their preservative efficiency in the natural environments, the establishment of the factors and levels influencing the maximal production would lead to a more effective recovery of these antimicrobial compounds from a defined laboratory culture medium. Specific environmental conditions, including those found in food, have been studied by Leroy and De Vuyst (2003) and Mota and Bradelli (2003) to determine their effect on the production of bacteriocins. According to Leal Sánchez et al. (2002), bacteriocin production changes dramatically upon altering the environmental conditions and optimum production may require a specific combination of environmental parameters.
High bacteriocin production in this study was obtained with MRS agar at $30^{\circ} \mathrm{C}$ after $24 \mathrm{~h}$. The absence of production recorded in BHI and M17 agar, suggested that specific nutrients were required for bacteriocin production. This result was consistent with that found by De Kwaadsteniet et al. (2005) where the highest activity of bacteriocin ST15 produced by $E$. mundtii ST15 was recorded after $14 \mathrm{~h}$ of growth in MRS broth at $30^{\circ} \mathrm{C}$. A low level of activity was recorded in M17 broth, BHI broth, soymilk and molasses.

Gino et al. (1993) reported that cerein synthesis and/or secretion was observed when $B$. cereus strain GN105 was grown in glucose-supplemented BHI broth at $30^{\circ} \mathrm{C}$, while no antimicrobial activity was observed for the growth in various other minimal or rich media. Also no bacteriocin was detected when strain GN105 was grown in BHI broth at $25^{\circ} \mathrm{C}$, while only a reduced amount of cerein was found at $37^{\circ} \mathrm{C}$. Similar results for $L$. plantarum strains ST23LD and ST341LD that were grown in BHI or M17 broth adjusted to $\mathrm{pH}$ 6.5 were described by Todorov and Dicks (2006). Growth of the latter two strains in $10 \%$ (w/v) soy milk or $10 \%(\mathrm{w} / \mathrm{v})$ molasses yielded low levels of bacteriocin production. The low activity levels recorded in M17 broth, BHI broth, soy milk and molasses, despite relatively good growth, suggested that the specific nutrients were required for the production of bacteriocin ST23LD and ST341LD. The production of these bacteriocins was much higher at $30^{\circ} \mathrm{C}$ than at $37^{\circ} \mathrm{C}$, which suggested that the growth temperature also played an important role. Some of the results obtained in this study were supported by the observation of Bizani and Brandelli (2002) on bacteriocin production from $B$. cereus $8 \mathrm{~A}$, which was higher at $30^{\circ} \mathrm{C}$ than at $25^{\circ} \mathrm{C}$. An important decrease in bacteriocin activity was observed at $37^{\circ} \mathrm{C}$. They deduced that the relationship between the growth and specific production rates, as a function of the temperature, showed different kinetics of the production. Also Guerra and Pastrana (2002) found that the nisin and pediocin produced by Lactococcus lactis and Pediococcus acidilactici obtained on whey were lower than those obtained on MRS broth. The same observation was reported by Liao et al. (1993) experimenting with $L$. plantarum UG1 when grown in whey permeates producing plantaricin UG1. Few publications also reported the feasibility of the production of both 
nisin and pediocin $\mathrm{AcH}$ bacteriocins in whey permeate.

Todorov et al. (2006) showed that L. lactis subsp. Lactis HV219 strain did not grow in MRS with an initial $\mathrm{pH}$ of 4.5. Low levels of bacHV219 were recorded in MRS broth adjusted to $\mathrm{pH}$ of 5.0. In the same medium adjusted to $\mathrm{pH}$ of 5.5 and 6.5 , bacHV219 was recorded. The highest level was recorded after $24 \mathrm{~h}$ in MRS medium adjusted to an initial $\mathrm{pH}$ of 6.0. The final $\mathrm{pH}$ values of the cultures were more or less the same $(\mathrm{pH} 4.5)$, irrespective of the initial $\mathrm{pH}$. (Todorov and Dicks 2007; Khalil et al. 2009) reported that the bacteriocin ST712BZ inhibits the growth of $L$. casei, E. coli, P. aeruginosa, E. faecalis, $K$. pneumoniae and L. curvatus. The growth of this strain in BHI, M17, soy milk and molasses was similar to the growth in MRS (pH.6.0), with optimal bacteriocin production recorded in MRS after $24 \mathrm{~h}$. The same level of bacteriocin production was recorded in MRS broth with an initial $\mathrm{pH}$ of $6.5,6.0$ and 5.5. Low levels of bacteriocin activity were recorded in MRS broth with an initial $\mathrm{pH}$ of 5.0 and 4.5, which was consistent with the present results.

\section{ACKNOWLEDGEMENT}

This study work was supported by the Microbiology Research Laboratory. Faculty of Sciences, Es-Senia University, Oran, Algeria.

\section{REFERENCES}

Abo-Amer. Characterization of a bacteriocin-like inhibitory substance produced by Lactobacillus plantarum isolated from Egyptian home-made yogurt. J Microbiol. 2007; 33: 313-319.

Bizani D, Brandelli A. Characterization of a bacteriocin produced by a newly isolated Bacillus sp. Strain 8 A. J Appl Microbiol. 2002; 93: 512-519.

Bromberg R, Moreno I, Delboni R, Cintra H, Oliveira P. Characteristics of the bacteriocin produced by Lactococcus lactis subsp. cremoris CTC 204 and the effect of this compound on the mesophilic bacteria associated with raw beef. J Microbiol Biotechnol. 2005; 21: 351-358.

Caplice E, Fitzgerald G F. Food fermentation: role of microorganisms in food production and preservation. Int J Food Microbiol. 1999; 50: 131-149.
Caridi A. Selection of Escherichia coli inhibiting strains of Lactobacillus paracasei subsp. paracasei. J Ind Microbiol Biotechnol. 2002; 29: 303-308.

Carr FJ, Hill D, Maida N. The lactic acid bacteria: A literature survey. Crit Rev Microbiol. 2002; 28: 281370.

Cintas LM, Casaus P, Holo H, Hernandez P E, Nes IF, Harvastein LS. Enterocins L50A and L50B, two novels bacteriocins from Enterococcus feacium L50, are related to Staphylococcal hemolysins. J Bacteriol. 1998; 180: 1988-1994.

Daeschel MA, McKenney MC, McDonald LC. Bacteriocidal activity of Lactobacillus plantarum C11. Food Microbiol. 1990; 7: 91-98.

De Kwaadsteniet M, Todorov SD, Knoetze H, Diks LMT. Characterization of a 3944Da bacteriocin produced by Enterococcus mundtii ST15, with activity against gram positive and gram negative bacteria. Int J Food Microbiol. 2005; 105: 433-444.

Dellaglio F, De Roissart H, Curk MC, Janssens D. Caractéristiques générales des bactéries latiques. In: De Roissart H, Luquet FM. Bactéries Latiques. 1994.

Diop MB, Dibois-Dauphin R, Tine E, Jacqueline AN Thonart P. Bacteriocin producers from traditinal food products. Base. 2007; 11: 275-281.

Garrity GM. Bergey's manual of systematic bacteriology. V 2. New York. 1984.

Gaur Y, Narayan K, Chauhan S, Ali A. Bacteriocinogeny: concept, nomenclature, prevalence and application. Indian J Microbiol. 2004; 44 (1): 130.

Gino N, Ezio R, Margherita S, Mauriljo DF. Antimicrobial activity of a newly identified bacteriocin of Bacillus cereus. Appl Microbiol American Soc. 1993; p. 4313.

Guerra NP, Pastrana L. Modelling the influence of $\mathrm{pH}$ on the kinetics of both nisin and pediocin production and characterization of their functional properties. Proces Biochem. 2002; 37: 1005-1015.

Haller D, Colbus H, Gänzle MG, Scherenbacher P, Bode C, Hammes WP. Metabolic and functional properties of lactic acid bacteria in the gastrointestinal ecosystem: a comparative in vitro study between bacteria of intestinal and fermented food origin. System Appl Microbiol. 2001; 24: 218-226.

Harrigan WF. Laboratory methods. In: Food Microbiology. California. Academic press. 1998.

Joshi1 VK, Sharmal S, Neerja SR. Production, purification, stability and efficacy of bacteriocin from isolates of natural lactic acid fermentation of vegetables. Food Technol Biotechnol. 2006; 44 (3): 435-439.

Khalil R, Elbahloul Y, Djadouni F, Omar S. Isolation and partial characterization of bacteriocin produced by a newly isolated Bacillus megaterium 19 strains. Botany Department Scien. Alexandria. Egypt. 2009; 8 (3): 242-250. 
Korenblum E, von der Weid I, Santos ALS, Rosado IAS, Sebastian GV, Coutinho CM, et al. Production of antimicrobial substances by Bacillus subtilis LFE1, B. firmus $\mathrm{H} 2 \mathrm{O}-1$ and B. licheniformis T6-5 isolated from an oil reservoir. Braz J Appl Microbiol. 2005; 98: 667-675.

Lade HS, Chitanand MP, Gyananath G, Kadam TA. Studies of some properties of bacteriocins produced by Lactobacillus species isolated from agro-based waste. Int J Microbiol. 2006; 2 (1):1-5.

Leal-Sánchez MV, Jiménez-Diaz R, MaldonadoBarragán A, Garrido-Fernandez A, Ruiz-Baeba JL. Optimization of bacteriocin production by batch fermentation of Lactobacillus plantarum LPCO10. Appl Environ Microbiol. 2002; 68: 4465-4471.

Leroy F, De Vuyst L. A combined model to predict the functionality of the bacteriocin-producing Lactobacillus saké strain CTC494. Appl Environ Microbiol 2003; 69: 1093-1099.

Lewus CB. Characterization of bacteriocins produced by lactic acid bacteria isolated from meat. Appl Environ Microbiol. 1991; p. 153.

Liao CC, Yousif AE, Chism GW. Pediococcus acidilactici PO2 bacteriocin production in whey permeate and inhibition of Listeria monocytogenes in foods. J Food Sc. 1993; 58: 430-434.

Line JE, Svetoch EA, Eruslanov BV, Perelygin VV, Mitsevich EV, Mitsevich IP. Isolation and purification of enterocin E-760 with broad antimicrobial activity against gram-positive and gram-negative bacteria. Antimicrob Agents chemother. 2008; 52: 1094-1100.

Martin-Visscher LA, Van Belkum MJ, GarneauTsodikova S, Whittal RM, Zheng J, McMullen LM, et al. Isolation and charachterization of Carnocyclin A, a noval circular bacteriocin produced by Carnobacterium Maltaromaticum UAL307. Appl Environ Microbiol. 2008; 74: 4756-4763.
Motta AS, Brandelli A. Influence of growth conditions on bacteriocin production by Bacillus linens. Appl Mirobiol Biotechnol. 2003; 62: 163-167.

Özlem E, Feryal E. Isolation and characterization of Lactobacillus bulgaricus and Lactobacillus casei from various foods. Food Engineer. 2006; 30: 39-44.

Parada JL, Caron CR, Medeiros ABP, Soccol, CR. Bacteriocins from Lactic Acid Bacteria: Purification, Properties and use as Biopreservatives. Biosci Biotechnol Biochem Braz. 2007; 50 (3); 521-542.

Parada JL, Sambucetti ME, Zuleta A, Rio ME. Lactic acid fermented products as vehicles for probiotics.In: New Horizons in Biotechnology. Kluwer Academc Publishers. Boston. Londres. 2003; p. 335-351.

Sanni AI, Onilude AA, Ogunbanwo ST, Smith SI. Antagonistic activity of bacteriocin produced by Lactobacillus species from Ogi, an indigenous fermented food. J Basic Microbiol 1999; 39: 189 195.

Schillinger U0, Lucke FK. Food Microbiol. 1987; 4: 199-208.

Tagg JR, Dajani AS, Wannamaker LW. Bacteriocins of gram-positive bacteria. Bacteriol Rev. 1976; 40: 722756.

Todorov SD, Dicks L M. Bacteriocin production by Lactobacillus pentosus ST712BZ isolated from boza. Braz J Microbiol. 2007; 38: 166- 172.

Todorov SD, Danova ST, van Reenen CA, Meincken M, Dinkova G, Ivanova IV, et al. Characterization of bacteriocin HV219, produced by Lactococcus lactis subsp. Lactis HV219 isolated from human vaginal secretions. J Basic Microbiol. 2006; 46 (3): 226-238.

Zuniga MI, Pardo S, Ferrer. Int J Food Microbiol. 1993; 18: 37-42. 
PÁGINA

EM

BRANCO 